Doyle, A., Kleinfeld, J., \& Reyes, M. (2009). The educational aspirations/attainment gap among rural Alaska native students. The Rural Educator, 30(3), 25-33.

\title{
The Educational Aspirations/Attainment Gap Among Rural Alaska Native Students
}

\author{
Aaron Doyle \\ Judith Kleinfeld \\ University of Alaska Fairbanks \\ Maria Reyes \\ University of Texas Pan American
}

Indigenous students in rural Alaska hold high educational aspirations and yet few students realize their educational goals (Hamilton \& Seyfrit, 1993; Kleinfeld \& McDiarmid, 1986; McDiarmid \& Kleinfeld, 1981). Our purpose in this study was to understand why so many Alaska Native students from small, isolated communities "drift" after high school, neither entering the postsecondary programs they aspire to, nor engaging in paid work. The contribution of this study is to clarify the reasons for the "educational aspirations-achievement gap," in other words, why so many Alaska Native rural students have high educational expectations, and yet remain directionless in adult life. This is an issue on which virtually no research has been done. This paper also suggests ways that rural schools and postsecondary institutions can assist Alaska Native students in obtaining the postsecondary education to which they aspire.

\section{Introduction}

The aspirations and expectations of rural Alaska Native youth are informed by factors quite different from youth in urban Alaska. Alaska's rural communities are extremely isolated with $80 \%$ off the road system, accessible only by boat or airplane. Many communities do not have running water or sewer systems - a cause of rampant disease, such as the highest incidence of hepatitis B in the state (Alaska Natives Commission, 2006).

Few sources of paid employment are available in isolated rural villages, particularly positions requiring postsecondary education. Most rural Native men are engaged in seasonal employment, such as construction and fire fighting. Employed women tend to work in clerical jobs, in the school as teacher aides or in other school support positions such as food preparation. Finding employment is particularly difficult for young people. Alaska Natives aged 20 to 24 have the highest rate of unemployment among the working age Alaska Native population, and rates of unemployment are highest among youth living in remote, rural areas of Alaska (Goldsmith, Angvik, Howe, Hill, \& Leask, 2004) is this a different formatting structure?. The Alaska Natives Commission (2006) reports that unemployment among Native men in one out of every eight villages is in excess of $50 \%$ and points out that these figures are much higher than such official estimates because of the large numbers of "discouraged workers" who are not counted as in the labor force. Traditional subsistence hunting and fishing remain important economic activities and sources of status for Native men. Still, low participation rates in the wage economy makes life difficult. Village residents face high prices and especially high energy costs. The effects of climate change are acute in the Arctic, eroding hunting opportunities.

Alaska Natives also face severe social problems. The Native mortality rate is more than three times the national average, with a substantial proportion due to alcohol abuse (Alaska Natives Commission, 2006). The rate of Fetal Alcohol Spectrum Disorders is over twice the national average. Rates of child physical abuse, neglect, and sexual abuse are more than twice the national average. While Alaska Natives comprise $16 \%$ of the overall Alaska population, they make up over $32 \%$ of the incarcerated population. Rates of suicide are extremely high, especially among young, rural Alaska Natives. While Natives ages 10 to 19 comprise $20 \%$ of the state's population, they account for $61 \%$ of the suicides (Yardley, 2007).

Despite intense and sustained efforts by the University of Alaska to increase the enrollment of indigenous students, just $14 \%$ of the total postsecondary enrollment in 2004 consisted of Alaska Native students (University of Alaska, 2004). Further, the number of Native students at the University of Alaska who leave without earning a degree is almost twice the rate of non-Native students (Goldsmith et al., 2004). Alaska rural schools have created numerous programs to help students find a direction for life after high school, such as career aspiration programs and trips to a range of postsecondary institutions, but no research has examined their success. 


\section{Review of the Literature}

The "aspirations-achievement gap" is common among minority youth and youth of low socioeconomic status (Kao \& Tienda, 1998) and a central source of "lost talent" (Hanson, 1994). Previous studies have attributed this gap to a range of problems, such as lack of information about college (Kao \& Tienda, 1998), poor grades, high high school dropout rates, and limited noncognitive skills such as time management and study skills (Roderick, 2006), low socioeconomic status and academic ability (Marini \& Greenberger, 1978), and the lack of a coherent and realistic life plan (Schneider \& Stevenson, 1999). Adolescent students aspire to "what they know or can imagine" (Haller \& Verkler, 1993). Michelson (1990) suggests that the "attitude-achievement paradox" among Black students reflects a difference between abstract and concrete attitudes toward the promise of education. Their abstract attitudes reflect popularly held beliefs about the importance of education to upward mobility, but their concrete experience, reflecting what they actually see, influences their actions. Alaska Native students see few concrete examples of other rural students who have graduated from postsecondary institutions.

Studies of Alaska Native youth have consistently found high stated aspirations for education combined with behavior undirected toward fulfilling their goals (Seyfrit \& Hamilton, 1992; Seyfrit, Hamilton, Duncan \& Grimes, 1998; McDiarmid \& Kleinfeld, 1981). These studies, however, have relied on structured questionnaires which give little understanding of the bases of the aspirationsachievement gap. The present study, to our knowledge, is the first to examine, through lengthy qualitative interviews, the mindsets of rural Alaska Native students at the end of high school and what influences students to pursue their postsecondary educational aspirations.

\section{Research Methods}

Working with rural school districts and schools, we interviewed 49 Alaska Native students (27 males and 22 females) at the end of high school (approximately two weeks before graduation) when ideas about the future are most developed and when students have taken or not taken concrete steps to fulfill their educational aspirations. These qualitative interviews centered on students interest in attending postsecondary programs, their occupational plans, and the influence of their parents, other family members, peer groups, and the educational and career programs organized by their high schools. Qualitative interviews enabled us to examine through a fine-grained analysis the contradictions and confusions that would not be evident in structured surveys.

All interviews were recorded on digital tape recorders so that the researchers could listen for voice tone and emphasis and sense of confidence. Notes on student background and interview observations were taken during fieldwork. Codes were developed through qualitative analysis, listening to the interviews time and again for themes that emerged. Themes were checked through the second researcher. The inter-rater reliability reached $90 \%$. The theoretical lens used to analyze the data was phenomenological, using grounded theory of individual cases (Glaser \& Strauss, 1967).

The interview began with the general open-ended question, "what are you thinking about doing after you finish high school?” Depending on their plan, students were asked questions in order to code if the student's idea was a vague hope or a thought-out, realistic plan. Next, the students were asked systematic questions about the influences of parents, teachers, counselors and peers, their attitudes about school and the necessity of more education. The interviewer then summarized the plan back to the student to be sure he understood the student's ideas correctly.

Three communities were randomly sampled from rural villages with small (300 to 600), medium (600_900), and large (900-1200) populations. All students signed consent forms, and school districts, individual schools, and the Institutional Review Board of the University of Alaska Fairbanks all approved the study. Students were paid \$10 for their participation. No student declined to participate. All interviews were digitally recorded.

To examine a year later whether the rural Native students had entered the postsecondary programs to which they aspired, we conducted follow-up interviews. Students were paid \$15 for their participation. All students were located, signed consent forms, and interviewed, most in their home villages and others in postsecondary programs.

Qualitative analysis of the initial interviews revealed an important difference among the rural students. Some were confused, changing their ideas about their future and their plans within the interview, or choosing occupations, such as doctor, while believing that training in Job Corp would prepare them for this aspiration. Others had far clearer ideas and had taken concrete steps to achieve their aspirations. We categorized the first group of rural Native students as "drifting" and the second group as "directed." A student was coded as "directed" if he or she showed two out of three characteristics: 1) a plan of any kind, 2) a plan where goals were linked to realistic means to attain them, and 3) concrete steps taken toward realizing their goals. It is important to emphasize that students who reported the choice of staying in their rural community and pursuing a traditional subsistence/ seasonal wage employment lifestyle were categorized as "directed." The issue was whether the student had developed a sense of what he or she wanted to do and had some idea of how to attain it.

Interviews of the directed and drifting students were then analyzed for the factors that influenced their ideas about the future, such as messages and support from family members and peers, support from teachers and counselors, and the influence of programs designed to help rural students find a 
future direction, such as trips to explore postsecondary possibilities, career exploration classes, and the Alaska Scholars Program, which provided a four year college scholarship at the University of Alaska for students in the top $10 \%$ of their graduating class.

\section{Findings}

Most of the rural students were drifting, the males (78\%) slightly more than the females (73\%). Those drifting students were more likely to report vocational aspirations (73\%) than students with direction. What stands out in these findings is that over $70 \%$ had done little or no planning. Students would say they planned to "go training" after high school but would not have any idea about where they would get this training or even what they would train for. Others could name a training program but did not know why they chose it.

We begin with two cases, a drifting and a directed male student at the end of high school, in order to clarify their contrasting mindsets and differences in their sources of support for their post-high school aspirations and plans.

\section{John: A Drifting Rural Alaska Native Senior}

Graduation day was a few weeks away and John was thinking about what to do next. After watching work crews on various construction projects around town, he was thinking about becoming a heavy equipment operator or carpenter, and he was pretty sure he would need some certification training to get these jobs. His mom and the school counselor had been encouraging him to go to a training program after high school. A training program sounded pretty good. He didn't see much to do in his village. He had been thinking about going to the city anyway, where he could have a nice house and a motorcycle.

Posters and flyers advertising colleges, vocational programs, and other opportunities covered the wall by the counselor's office. He saw one for the Alaska Vocational Technical Center (AVTC), and a friend gave him an application. His enthusiasm dimmed after looking at the form. There was a lot to fill out — a background history, social security information, and program and housing choices. Applicants had to show how they would pay for the program. John had never really thought about that. He needed to send a birth certificate, too, and he had no idea how to get one. On top of it all, there was a $\$ 25$ fee just to submit the application. (John did not understand the actual requirements. AVTC does not require an application fee and the program charges no tuition for low-income students.)

John's frustration mounted, and he put the paperwork aside to fill out later. His misgivings continued. He had gone on school trips for sports and career development activities, but these were always school-organized events. He was conflicted about leaving his village. On the one hand, he complained about how boring his village was, but he enjoyed life there-playing basketball, riding his snow mobile and going out hunting.

He also was not too sure he had a good enough education to make it in a training program. His grades were not good, and since he had not passed the reading portion of the state's High School Graduation Qualifying Exam, he would only be receiving a "Certificate of Achievement" when he left high school. Several older friends and relatives had gone off to training programs or college but had dropped out after a few months. John did not want that to happen to him.

Maybe this training thing just was not right for him now. After all, he had made pretty good money working in a fish processing plant last summer and he had heard that there could be some fire-fighting jobs coming up next summer. He was not too worried about supporting himself, he could still live at home or with relatives. Many of his older peers were still living with their parents.

The application sat until he chanced upon it on the last day of school when cleaning out his locker, too late to send it in for the fall admission deadline. He would take a year off, go to a training program later and maybe apply next year.

Interviewed a year later, John said he was just a "regular village dude." Asked what being a "regular village dude" involved, he responded, "Just living life ... get up, eat, find something to do, check out my friends, hang out with them.

\section{Rick: A Directed High School Senior}

Rick liked working on snow mobiles and was thinking about becoming a mechanic, maybe a carpenter, maybe a teacher. He considered a training program but was confused by the options, intimidated by the paperwork, and doubted the quality of his high school education. He was not sure where to go or how to get there. Maybe he should take a year off and think about it; something might come up. There was the fish processing plant where he could work in the summer, and he could live with his family and maybe play on the city league basketball team.

Then a friend told Rick they should join the Army National Guard together. The friend said it would be fun, they would get to shoot guns and operate big equipment. They would get $\$ 8,000$ a year plus a signing bonus. All he needed to do was sign up, and the Army would take care of everything. Rick already knew many relatives and friends who were in the Guard. They did one weekend a month and two weeks in the summer, living at home most of the year, picking up seasonal work, going hunting, and playing basketball at the school gym.

Rick thought that it all sounded pretty good. So he enlisted with his friend and was due to report for Basic Training down in Ft. Benning, Georgia, in a few weeks. A year later, Rick had done well in the military.

Rick and John were both confused about what to do after high school. But John ended up on his own, with no idea 
about how to fill out an application form, misunderstanding the costs of the program, uncertain of his abilities, and confused about whether to stay or leave his village. Rick found an attainable direction in the military, a structured pathway where all he had to do was sign up, and a friend to provide support.

Both Rick and John had grown up in a village context which provided few role models of paying jobs for males. Women, in contrast, were employed as teachers, teacher aides, nurses and government workers. John saw no structured pathway which would lead him out of the village and into the occupation to which he aspired-becoming a heavy equipment operator or a carpenter. Indeed, the Alaska Vocational Training Center, did not actually train young people for either of these occupations. Rick, in contrast, saw a highly structured option - the military - which provided a clear location, training and pay. He also had a friend who would go with him and saw role models of others in the community who had successfully completed military training.

The qualitative interviews revealed these themes:

Theme 1: Most rural students had high educational aspirations, wanting to go to vocational school or college, and most had occupational aspirations that required some type of postsecondary education.

Of the 49 students, $61 \%$ said they wanted to go to college and $63 \%$ said they wanted to go to a vocational program (Some students named more than one educational aspiration). Female students (73\%) were more likely to want to go to college than male students (52\%). Male students talked about vocational school (74 \%) more than female students (50 \%). Over half (53\%) named occupations that required a college degree. However, many students' ideas were vague and confused with their plans and ideas shifting within the interview. One girl wanted to go to college, but at the same time did not want to leave high school and expressed fear of leaving for college saying, "It's like taking a step out of your old life." The students knew of educational programs that prepared them for college but often didn't want to go because "I don't want to go away when I need to work." One boy had an eclectic mix of aspirations, to be a teacher, a storeowner, a plumber, an electrician, and a youth program coordinator. He had not connected these occupations to different postsecondary programs.

Students were dissatisfied with what they had learned in school and wanted more challenging classes:

Female: "We didn't get a good education. You only have to be at seventh grade math for levels for the standards to pass. You can go on to higher education but the teachers focus on the low end."

Male: "I don't think I have enough knowledge to go on to college. It (high school) is just too easy, the graduation requirements and the standards they have."

The students were correct about the low quality of education they were receiving. Data from the Alaska Department of Education and Early Development showed that 60 to $90 \%$ of the students were not proficient in reading, writing, or math on the Alaska High School Graduation Qualifying Exam.

All of the students were thinking about going to college or training, but the average grade point average was 1.7failure. Even the students with extremely low GPAs were quite often thinking about going to college. In some cases, those with the lowest academic indicators had the highest aspirations, such as the aspiring teacher who had a GPA below 1.0 or the hopeful doctor who had less than a 2.0 GPA. Of those students with a $1.0 \mathrm{GPA}$ or lower, $83 \%$ were thinking about going to college. To our surprise, the Alaska Department of Education and, less surprising, the individual rural school districts did not release the student achievement scores on objective tests to the public, based on an exhaustive web search. The National Assessment of Educational Progress also does not enable the analysis of data by Alaska's rural school districts but only offers more general state analyses of students who fall below basic, basic, proficient, and above proficient in reading, writing, mathematics and such school subjects as history, geography, and civics.

The sample schools, however, were all chosen on the basis of being on the state of Alaska's Department of Education and Early Development's lists of low performing schools, where $95 \%$ of students are Alaska Natives and 76\% did not meet AYP. In the Northwest Arctic region, $91 \%$ of the students are Alaska Natives and $77 \%$ of the schools did not meet AYP. (McDowell Group, 2005: 2, 61).

Only in one community, which has a Native principal, did students express confidence about the quality of their education. In a large community with a high level of social problems, students expressed the least confidence in the quality of their high school education.

While most students aspired to college or some other type of postsecondary education, few students (6\%) thought higher education was "necessary" for them, while $35 \%$ gave a definitive "no" and the remainder gave mixed and qualified answers. Some students drew urban-rural distinctions. "Around here you can do pretty good without having education "cause people in the city need money to buy food but here you can just hunt and fish.”

Nonetheless, most students (73 \%) enjoyed going to school. Several stated how much they were going to miss high school after graduation and how they wished they could stay in school. As one rural student said, "School is fun. There is a lot to do and it keeps my brain working." For others, going to school provided something to do with their time. As another student put it, "There is something to do at school, nothing to do at home." On the other hand, less than 
$49 \%$ thought they had received a good education, and this belief undermined their confidence that they could succeed in postsecondary education.

The University of Alaska Scholars Program did make a difference for students with high grades. The University of Alaska offers a four year tuition scholarship to all seniors in the top $10 \%$ of their graduating class. Of the 49 students, five students had received this scholarship. Earning this award and becoming a member of a select group was a catalyst for developing educational plans. One male recipient, for example, said that since he had won the UA scholarship he might as well try college. The award requires that students enroll in the fall semester, which prevented rural students from drifting, postponing educational plans, or taking a year off. The University of Alaska Scholars Program also maintains communication with students and organizes pre-college programs, such as camps before college, which create a group of friends who enter their first year together and stay together due to campus support programs for rural students, which assist them in choosing classes and getting tutoring. These support programs also organize social events where students enjoy traditional foods and see other rural students who have done well in college.

Theme 2: Very few students knew how to go about attaining their educational aspirations or were taking steps to reach their educational goals.

Of the 49 students, $76 \%$ had no realistic plans for attaining their aspirations with no important difference between the males (78 \%) and the females (73\%). Some students would say they planned to "go training" after high school but often would not have any idea about where they would get this training or even what they would train for. Others could name a training program but did not know why they chose it. Some students said they would be planning to "go college" but would not know which college, how to apply, or how to pay for tuition and living costs.

Some students showed no relationship between their stated aspirations and their plans for achieving them. For example, students would have high career aspirations, such as becoming a doctor or engineer, but had not filled out any college applications. Some would be thinking about going to a postsecondary institution that did not prepare them for the occupation that they were interested in pursuing, such as a girl who planned to go to the Job Corps to become a surgeon.

Commonly, these students had picked up an application to a postsecondary program but not sent it in. One student had an application but said she was "too busy" to fill it out, saying, "I'll wait until graduation, until after I'm ready to go." Students frequently putting off filling out applications, instead choosing to "wait and see what happens.
Theme 3: Most students said their families and counselors encouraged them to go to postsecondary education. But vague encouragement translated into action on the part of the students only when concrete and sustained messages accompanied it.

Most students (80 \%) said their families encouraged them to attend postsecondary education, a finding similar to that of Seyfrit \& Hamilton (1992). Students with vague and confused plans, however, could not mention specific help they had received from their families. Directed students talked not only about their families encouraging them but also about how their families helped them in filling out applications and applying for scholarships. A girl with both college aspirations and a high level of planning, for example, described her family as "really supportive" and her older siblings as "pushing me" and "making me get what I want . . . They make sure I am passing my classes and lecturing me so they're keeping me going.” One young man described how his grandfather made quite an impression when he told him. "If I were you I'd go training or do something and not come back, and I told him that's what I plan on doing . . . that's one thing that made me think...I don't want to be in this community for long." A mother further explained the problems faced by her son, a recent high school graduate. “He didn't want to live at home, but he didn't want to leave home either. His entire family lived nearby.

The majority of students (74 \%) reported that their school counselors had helped them regarding ideas about what to do after high school. But for most of these students, talking to counselors was not enough to help them make realistic plans or take any action. As with family support, the difference depended on the type of help the students received. Students who were taking steps toward attaining their plans said that their counselors did more than give advice and hand out information; they also helped them choose and apply for a postsecondary program and scholarships and submit their applications.

Educational and career development trips and visits to rural schools from representatives of postsecondary schools had little impact on students. We were surprised at how little difference expensive educational and career exploration trips and career development classes had on rural students. "This career development class was supposed to help you, like, get a career you want, but it didn't help me," said one rural young man. One young man commented on a recent school trip to the University of Alaska, Anchorage and Job Corp where they toured the campus and sat in on classes. "I didn't have any ideas of how colleges and vocational schools looked ... UAA wasn't as big as I thought it was. Gave more of an idea of how colleges look and how to get around." Indeed, only $45 \%$ reported that such activities had helped them. An example is a young man who had been accepted into a state university and was set to start in the upcoming fall semester. While the educational exploration 
trip to college campuses and the required Career Development class had made little difference, this young man also had received little concrete help from his counselor. "I never saw him,” he said, “and he didn’t care.”

While college and vocational program representatives had visited the schools in the fall, these visits were only mentioned by few students and did not appear to have made any impact. Involvement with a church youth group, however, did make a difference. Some students spontaneously mentioned they had taken church-organized trips to the campuses of the parochial colleges affiliated with their church. "The church took me to this college and I kind of liked it." Most importantly, the church youth groups followed up these trips by holding fundraisers to support the several students who wanted to go to the parochial college. This sustained combination of perspective-broadening trips and tangible support provided youth group students with direction that many other students did not have.

Theme 4: Directed students often had peers with aligned career ambitions.

Peers were an influence on educational plans for a majority of the directed students (83\%). For example, two boys had enlisted together in the Army after talking to an older peer. One boy told the interviewer, "I had a friend who just came back for Army National Guard training and said it was fun. Since my friend was doing it, I decided to go along with it."

Students often drew distinctions between what rural and urban life required:

Male 1: "Around here you can do pretty good without schooling or having education 'cause people need money to buy food . . . but here you can just go out hunting. It's good around here, not like the cities."

Male 2: "You can do fine around here just getting your own business started. But if you're in the city you need that college diploma."

The students who did not want to move to the city were usually male and their reason for remaining was primarily based on their enjoyment of a rural lifestyle. One boy expressed it this way: There is not as much people here, when I go into the city it feels kinda crowded, out here you know everybody...anytime you want to go boat hunting or something or take a boat ride it's right there.” But girls often wanted to move away. As one girl put it, there was nothing to do in her village but "get stuck and sit around and grow old.” Male students put it this way when asked if they would plan on doing subsistence after high school:

"Of course, I love going out hunting.”

\author{
"The outdoor life is the best way." \\ “It’s my life.” \\ "Subsistence is one of the funnest things I know."
}

One girl explained why she enjoyed life in the village: I can go out whenever I want without being supervised, with my mom not being worried about it, go snow mobile riding, camping, where I know everybody and everyone knows me. I'm pretty much related to everybody here.” A boy said, "I like it here, a lot of subsistence hunting, it's not too big where you get to know all, everybody in this town." This pattern was observed so often (59 \%) that a code was created to quantify it, showing that the majority of the total students held conflicting aspirations between leaving and staying. Almost three-fourths of the vocational students held such attitudes.

The following quotations are examples of students who were caught between wanting to stay and wanting to go:

Female student 1: I want to live in Anchorage, but at the same time here too, but there's not that many jobs here . . . seems like everyone is going to Anchorage."

Female student 2: "I don't want to go to the city, but I want to. I want to further my education . . . In the village is a lot better than staying in the city."

The following male student was conflicted about leaving but thought he could come back periodically. This plan to go back and forth from the village was a common theme.

Male student: "It is hard to leave this town." Interviewer: "What's hard about leaving?" Male student: "My family, friends, hunting, all kinds of things I like to do."

When asked about his reasons for leaving the boy responded, "For the job, the money, to have fun." He said he plans to come back to the village "40 times per year."

Just $54 \%$ of the students had a clear, thought-out plan and $69 \%$ of the students showed evidence of such conflict. Most students (two-thirds) were choosing to "wait and see what happens" or to "take a year off” as a way of resolving such conflict.

Usually the desire to move to the city was vague and unfocused. The students did not know what they would do in the city; they just wanted to get out of the village.

Interviewer: "Where would you like to live?" Female student: "Anywhere but this place." Interviewer: "Why?"

Female student: "Well, because not really much people have jobs here.” 
Interviewer: "Is one place more attractive to live than another?

Female student: "Maybe most likely Anchorage.” Interviewer: "Why Anchorage?"

Female student: "Could get a job anywhere."

Interviewer: "What kind of jobs would you look for if you went to Anchorage?"

Female student: "I don't know.”

\section{Conclusion: The Mindset behind the Educational Aspirations-Achievement Gap among Rural Alaska Native High School Seniors}

This study replicated the educational aspirationachievement gap found in many minority and low-income students and extended this finding to rural Alaska Native students. While most students did have high educational aspirations, many were confused and few had taken steps to realize their goals. Families and counselors, no matter how much they recommended postsecondary education, no matter how many expensive trips rural schools organized to familiarize students with options, were successful only when their encouragement was followed up with direct, personalized assistance to students, such as working with them to fill out applications and find scholarships. Rural students also doubted that the quality of their high school education actually prepared them for postsecondary education, a source of insecurity which prevented them from taking steps to fulfill their educational aspirations.

Structured pathways also made a difference. Some students joined the National Guard or the military because they perceived this experience as "fun because you get to learn how to shoot guns," but also as providing a clear route to the future. One boy said, "I had a friend who just came back from Amy National Guard Training a couple of months ago and said it was fun. My friend was doing it so I decided to go alone with it. I just joined up.”

The Alaska Scholars Program, which provided scholarships for the highest ranking student in each senior class, structured such a pathway to college and sparked concrete assistance from counselors and families. While voicing the slogan about the importance of education, very few students perceived education as 'necessary.' Many students, conflicted about staying in the village and venturing out, resolved this psychological conflict by figuring that they would "take a year off" or apply "next year." Students frequently mentioned an older classmate or relative. "He went off to college or training only to drop out and come back home. I can't think of anyone who completed college. I don't want to drop out and come back home." Another said, "There is something to do at school, nothing at home. School I can be with my friends.” Another boy put it, "I don't know if I really need school."

\section{The Follow-up Study One Year Later}

When we returned to the villages to re-interview the students, every student was either interviewed or tracked through their families. Of the 49 students, $71 \%$ were in the villages. Of those living elsewhere, $60 \%$ were female, a pattern consistent with Hamilton \& Seyfrit's (1994) concept of "female flight." Approximately half of the total group had neither earned a high school diploma nor retaken and passed the High School Graduation Qualifying exam. All the students contacted were happy to participate in the followup interview. The students identified as "drifting” continued to drift, treading water and waiting for something to happen.

Those students who had been considered "directed" were indeed more likely to have followed through with their plans, but most had not succeeded. Of the 30 students who were thinking about going to college in the initial interviews, just six students (3 males, 3 females) had enrolled in college. Of those who went to college, all but one dropped out, usually within one semester. This exception was the young woman who had chosen a parochial college and was supported by her religious community. The primary reason students gave for leaving college was that a "family issue" came up and that they had to return home for a time, which caused them to fall behind in their classes. A year later, these students were wishing they had stayed at college and wanted to go back. At least one had lost a scholarship due to poor grades during the first semester and was not sure what to do next.

Of the 31 students who wanted to go to a vocational training program (note that students often expressed more than one aspiration in the initial interview), just two students went-a young woman to Job Corps and a young man to a short summer carpentry program. The young man completed his program, and the young woman was still in Job Corps during the follow-up interview.

Four students, all males from the same community, joined the military, and these students were still participating and doing well. These young men were following the "peer cluster" pattern, where a group of friends decided to enter a program together and provided support for each other.

Most of the village young people, however, were drifting. As one young woman said wistfully in the follow-up interview, “I just let my days go by. It's like when I plan it never works out.”

\section{Conclusion: Research and Policy Directions}

This study was confined to three rural villages and future research needs to extend such qualitative interviews and carry out lengthier ethnographic work in many more communities with more varied economic contexts, where educational aspirations appear to differ (Hamilton \& Seyfrit, 1993). The influence of church groups on postsecondary achievement should be particularly examined. We did not anticipate their influence and did not examine it 
systematically. Nor were we able to examine the potential of selective boarding schools which offer high quality secondary education and assume postsecondary attendance for their graduates, high school programs which combine a secondary school education with college classes or high school programs which offer participation in postsecondary technical programs away from home as part of the high school experience.

Native students' perceptions that they have not received an adequate high school education are largely correct and an underlying source of their ambivalence about pursuing postsecondary education. Improving the quality of village schools so that students are successful on the High School Qualifying Exam should be a major policy concern in rural education. The percentage of Native tenth graders who reach proficiency in remote rural villages is low. In the rural region in which we carried out this study, for example, only $27 \%$ of Native tenth graders were proficient in reading, 62 $\%$ in writing, and $43 \%$ in mathematics (Goldsmith et al., 2004). This goal requires teachers to spend more time in rural communities to develop culturally relevant teaching methods, instead of using rural schools as a stepping stone to urban teaching jobs. It also requires the employment of more Native teachers rooted in the community who can develop connections between the standard curriculum and students' cultural experience. On average, just $5 \%$ of Alaska teachers are Native, varying from almost none in a few districts to about 30\% in others (Goldsmith et al., 2004).

School districts and counselors need to recognize the limitations of expensive postsecondary and career exploration trips in helping rural students find direction. Such programs expose students to opportunities, but it is counselors and parents who provide personalized guidance and direct help with applications and scholarships that encourage students to take advantage of these opportunities. Counselors are too often occupied with paperwork and lack the time to provide such concrete assistance. Counselor aide programs, aimed especially at returning college students, would help both to free counselors to provide direct help and encourage college students who have left school to return or locate some other postsecondary program. In addition, career programs that are structured as several weeks or semester long experiences may be effective.

Finally, structured pathways to postsecondary enrollment are important. Postsecondary institutions could emulate the Alaska Scholars Program, the National Guard, and church organizations in finding ways to provide clear structure and support. For example, cohort programs, which enroll a group of friends, are promising avenues for these rural students.

The large population of Native young people in rural Alaska makes the problem of students without direction and the skills to get well-paid employment acute. More than 60 $\%$ of Alaska Natives live in rural villages with large numbers of children (Alaska Native Commission, 2006). Preparing this group of young people for a satisfying and productive adult life is a serious policy problem for Alaskan society and for Alaska's rural educators.

\section{References}

Alaska Natives Commission. (2006). Key facts and findings. Retrieved October 28, 2008 from http.www.alaskool.org/resources/anc/anc06.htm

Glaser, B G. \& Strauss, A. L. (1967). The discovery of grounded theory: Strategies for qualitative research. Chicago: Aldine.

Goldsmith, S., Angvik, J., Howe, L., Hill, A., and Leask, L. (2004). The status of Alaska Natives report 2004. Anchorage: Institute of Social and Economic Research.

Haller, E. J., \& Virkler, S. (1993). Another look at ruralnonrural differences in students' educational aspirations. Journal of Research in Rural Education, 9(3), 170-178.

Hamilton. L. C., \& Seyfrit, C. L. (1993). Town-village contrasts in Alaskan youth aspirations. Arctic, 46 (3), 225-263.

Hamilton, L. C., \& Seyfrit, C. L. (1994). Female flight? Gender balance and outmigration by Native Alaskan Villagers. Arctic Medical Research, 53(Supplement 2), 19-193.

Hanson, S. L. (1994). Lost talent: Unrealized educational aspirations and expectations among U.S. Youths. Sociology of Education 67, 159-183.

Kao, G., \& Tienda, M. (1998). Educational aspirations of minority youth. American Journal of Education, 106, 349-384.

Kleinfeld, J. S., \& McDiarmid, G. W. (1986). The occupational values of rural Eskimo compared to urban White adolescents. Journal of American Indian Education, 25(3), 19-22.

Marini, M. M. \& Greenberger, E. (date?)Sex differences in educational aspirations and expectations. American Educational Research Journal, 25 (1), 67-69.

McDiarmid, G. W., \& Kleinfeld, J.S. (1981). Doctor, lawyer, Indian chief: The educational and occupational aspirations, plans, and preferences of Eskimo students on the Lower Yukon. Anchorage: Institute of Social and Economic Research.

Michaelson, R. A. (1990). The attitude-achievement paradox among Black adolescents. Sociology of Education, 63, 44-61.

Roderick, M. R. (2006, April). Closing the aspirationsattainment gap. Implications for high school reform: A commentary from Chicago. Manpower Demonstration Research Corporation. Retrieved October 28, 2008 from http://www.studentclearinghouse.org/highschools/pdfs/ MDRC_CPSstudy.pdf

Schneider, B. \& Stevenson, D. (1999). The ambitious generation: America's teenagers motivated but directionless. New Haven: Yale University Press. 
Seyfrit, C. L. \& Hamilton, L. C. (1992). Alaska Natives and their attitudes toward education. Arctic Anthropology, 35 (1), 135-148.

Seyfrit, C.L., Hamilton, L. C., Duncan, C. M., \& Grimes, J. (1998). Ethnic identity and aspirations among rural Alaska youth. Sociological Perspectives, 41 (2), 343365.

University of Alaska (2004). University of Alaska student enrollment summary: A review of the enrollment changes 1997 to 2004 and a listing of current student enrollment statistics: Fairbanks: University of Alaska, The Office of Statewide Planning and Budget Development.
Yardley, W. (2007). One of the world's highest suicide rates: Native Alaskan villages. International Herald Tribune. Retrieved Oct. 24, 2008 from http:///www.iht.com/articles/2007/05/14/news/ alaska.php 